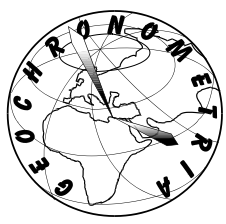

Conference Proceedings of the $12^{\text {th }}$ International Conference "Methods of Absolute Chronology" May 11-13 ${ }^{\text {th }}$, 2016, Gliwice-Paniówki, Poland

\title{
PLEISTOCENE GLACIATIONS OF THE SE ALTAI, RUSSIA, BASED ON GEOMORPHOLOGICAL DATA AND ABSOLUTE DATING OF GLACIAL DEPOSITS IN CHAGAN REFERENCE SECTION
}

\author{
ANNA R AGATOVA ${ }^{1,2}$ and ROMAN K NEPOP ${ }^{1,2}$ \\ ${ }^{I}$ Sobolev Institute of Geology and Mineralogy, Russia, 630090 Novosibirsk, Ak. Koptyuga av., 3 \\ ${ }^{2}$ Ural Federal University, Russia, 620002 Yekaterinburg, Mira str., 19
}

Received 25 June 2016

Accepted 9 February 2017

\begin{abstract}
Geomorphological evidence of at least two Pleistocene glacial epochsis noted within the Chagan-Uzun river basin, SE Altai. A review and analysis of all available absolute dates for reference Chagan section is presented. The highest correlation amongst all TL dates is observed for the lens of glacio-lacustrine sediments - the most suitable among glacial deposits for luminescence dating, and indicates its possible Middle Pleistocene age. IRSL dates obtained from feldspar indicate a Middle Pleistocene age of moraines already in the upper part of the section. The small number of obtained IRSL dates does not allow making geochronological reconstructions of the Pleistocene glaciations, but gives the possibility for further experiments with different variation of OSL (IRSL) techniques. Strong low temperature peak in TL signal and strong response to IR stimulation are specific regional quartz features, which could be explained by combination of short transportation distance and low number of depositional cycles for mineral grains. Available radiocarbon dates of carbonate concretions from this section are not related to the age of moraine sedimentation and most likely indicate the period of the Chagan river incision into the ancient glacial deposits.

This study has shown that TL method is not valid for dating glacial sediments and TL dates cannot be utilized as chronostratigraphic markers. Generally, the Chagan section could hardly serve as a reference section for the Altai stratigraphy; available depositional correlation schemes for the Russian Altai and Siberia which are based on several TL dates obtained in the last century needs to be improved.
\end{abstract}

Keywords: Pleistocene, glacial sedimentation, luminescent dating, radiocarbon dating, Chagan section, Russian Altai.

\section{INTRODUCTION}

Reconstruction of the patterns of Pleistocene glaciations in the mountains of Southern Siberia, as well as correlating the sediments within mountains of Central

Corresponding author: A. R. Agatova

e-mail: agatr@mail.ru
Asia mountain belt and platform areas of Siberia, is not possible without absolute dating of glacial deposits, but these types of continental sediments are very complex to date absolutely. By now there is a wide arsenal of different numeric techniques for age determination of Quaternary sediments (Wagner, 1998). The application, precision and accuracy of each of them vary considerably (Fuchs and Owen, 2008).

However, within the Russian Altai utilizing most of techniques are highly problematic. Organic material gen- 
erally is not presented in ancient glacial sediments. Moreover, glacial sequences are beyond the radiocarbon timescale and geological materials suitable for other radiogenic dating methods are also absent. Cenozoic formation of the Russian Altai was not accompanied by volcanic activity unlike to the mountain systems of the neighboring Tuva region where at least 5 glaciations were revealed for the last 1.75 million years (hyaloclastites, the products of subglacial volcuno eruptions were dated using the K-Ar method (Yarmolyuk and Kuzmin, 2006)). In contrast to Tuva, the effusive and tephra layers are absent in the sections of the Russian Altai. Repeated developing giant ice-dammed lakes in the region (Butvilovsky, 1993; Carling et al., 2002; Rudoy, 2005 and Herget, 2005) complicate utilizing terrestrial cosmogenic nuclide dating of ancient moraines within intermountain depressions. Besides the difficulties of applying the numerical dating techniques, in glacial sediments of Altai reference sections there is a lack of finds of macro- and microfauna (ostracods), and species composition does not allow establishing the glacial sequences. Palynological analysis is ineffective because of the significant redeposition of the pollen. Main reference sections in the Russian Altai also do not contain deposits that could be clearly and reasonably interpreted as interglacial ones. Thus, despite of more than 150-year history of investigations, the Quaternary of the Russian Altai is still poorly understood with the number and chronology of glacial cycles unknown and the proposed extent of glaciations varying widely between different authors.

Now thermoluminescence (TL) dates of glacial deposits in several areas of the Russian Altai form the basis for the formal Altai Pleistocene stratigraphic scale and depositional correlation schemes for the Russian Altai, Altai foothill plains, Western and Eastern Siberia (Volkova and Babushkin, 2000; Quaternary System, 2008 and Volkova et al., 2010). These data were obtained in the 1980s using the TL dating technique with artificially saturated etalons (Il'ichev et al., 1973 and Svitoch et al., 1978). Even then it was stressed that "taking into account the weak theoretical elaboration of the method, all given TL dates, should be regarded only for comparative analysis as relative measure of the deposits ages (olderyounger)" (Svitoch et al., 1978, p. 16). The Chagan section, located in the southeastern part of the Russian Altai (SE Altai), is one of the most representative sections of the Altai Quaternary deposits. It includes more than a hundred-meter thickness of Pleistocene glacial sediments. A comprehensive study of this section was carried out in the 1970s and included TL dating (Svitoch et al., 1978). Eight TL ages, only three of which characterize the glacial and associated sediments in the upper part of the section, were taken for making geochronological reconstructions and first correlation schemes (Svitoch et al., 1978 and Arhipov et al., 1982).

Subsequently, a new set of absolute dates describing glaciations in this part of Central Asia was presented. For sediments of the Chagan section first TL dates utilizing naturally saturated etalons were published (Sheinkman, 1990) and several radiocarbon dates of carbonate concretions were obtained (Butvilovsky et al., 1996).

In this paper, we analyze tectonic and climatic factors that controlled the number and extension of the Pleistocene glaciations in different parts of the Russian Altai; present the results of our geomorphological investigations within the SE Altai with the main focus on the ChaganUzun river basin, where traces of different glaciations are preserved in topography; and finally compare these results with the results of applying different absolute dating techniques (previously published and obtained in this study) for dating glacial sediments of the reference Chagan section located within this basin. We also present the first experience of applying the IRSL method for feldspar from this section; discuss applicability of different luminescence techniques for dating the Pleistocene glacial sediments in the region and correlating these deposits with Siberian stratigraphic scales. The relevance of this work is evidenced by the interest of some international teams in studying and dating glacial features in Central Asia including Russian Altai applying various numerical techniques (Gribenski et al., 2014 and Stroeven et al., 2015).

\section{REGIONAL SETTING}

\section{Regional oroclimatic features controlling the Pleisto- cene glaciations of the Altai intracontinental uplift}

The Altai intracontinental uplift is a part of global watershed between the Arctic Ocean basin and the inland drainage basin of Central Asia (Fig. 1). The Altai Mountains are the northern part of the Central Asia collision belt. This mobile zone is clamped between Eurasia plate on the north and Djungar together with Tuva-Mongolian microplates on the west and on the east (Molnar and Tapponnie, 1975 and Novikov, 2004). As a result, the Altai intracontinental uplift stretches northwest more than $1500 \mathrm{~km}$ and forms a wedge shape narrowest in the southeast (about $50 \mathrm{~km}$ ) and widest in the northwest (up to $500 \mathrm{~km}$ ). The elevation increases in the opposite direction from $400 \mathrm{~m}$ a.s.l. to $4000 \mathrm{~m}$ a.s.l. In its northern part, the socle surface ${ }^{1}$ of the uplift is complicated by a sublatitudinal steep scarp from $500 \mathrm{~m}$ high in the west to $1250 \mathrm{~m}$ in the east (Ufimtsev, 2002), which together with the other sub-latitudinal faults forms tectonic steps with altitudes about 1000, 2000 and 3000 m a.s.l. (Bogachkin, 1981). The modern climate of the region is determined by its intracontinental position, with the main humidity transfer from the west (Atlantic Ocean) and to a lesser degree from the north (Arctic), with a dominant influence of the Mongolian anticyclone, giving rise to increasing aridity southeastwards: annual precipitation decreases in

\footnotetext{
Socle surface is the surface contacted minimum marks of relief. A surface contacted top of mountains is summit surface.
} 


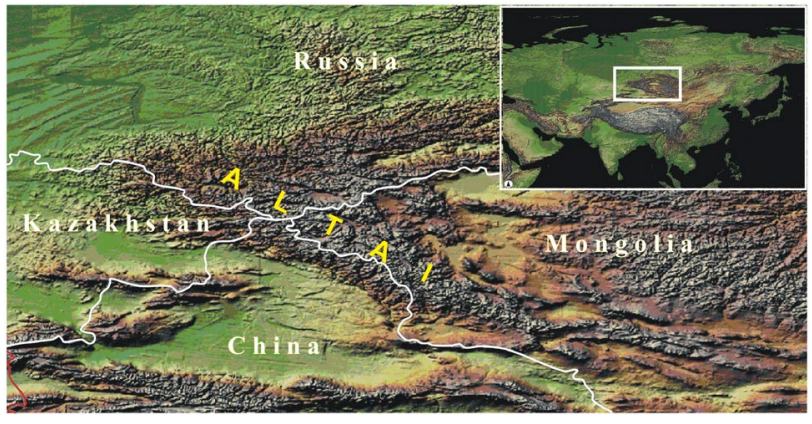

Fig. 1. Location of the Altai Mountains.

this direction from $1000 \mathrm{~mm}$ in the northern part of the Lake Teletskoe depression (Selegey and Selegey, 1978), down to 150-200 $\mathrm{mm}$ within the bottom of the Chuya intermountain depression (Rusanov, 1961). This is resulted in complicated latitude-longitude orographic climatic zoning. This zoning is the most pronounced within the Russian Altai with its most complex structure for the whole Altai Cenozoic uplift. It determines glaciation patterns as well as varying preservation of ancient glacial landforms and deposits in different parts of the Russian Altai. Together with facies heterogeneity of deposits, interruptions in sedimentation, sparse distribution of reference sections, this results in different interpretations of amount, size and ages of the Pleistocene glaciations in the region. The problem of absolute age determination of glacial and associated sediments is another reason of inconsistency in existing views on this issue.

Within the Russian Altai the following areas, which are different in orographic and climatic features and therefore in manifestations of ancient glaciations, could be defined (Fig. 2). They are presented in a southward direction - in the direction of decreasing humidity and increasing altitudes (Fig. 3):

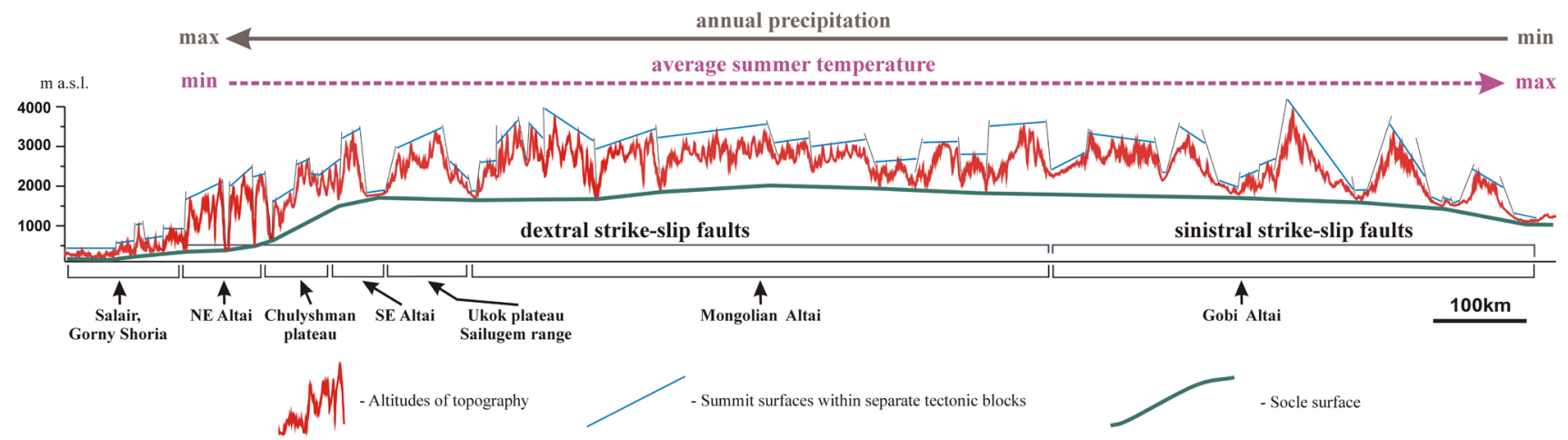

Fig. 2. Neotectonic profile across Altai Mountains (See Fig. 3 for profile location) and trends of average summer temperature and annual precipitation.
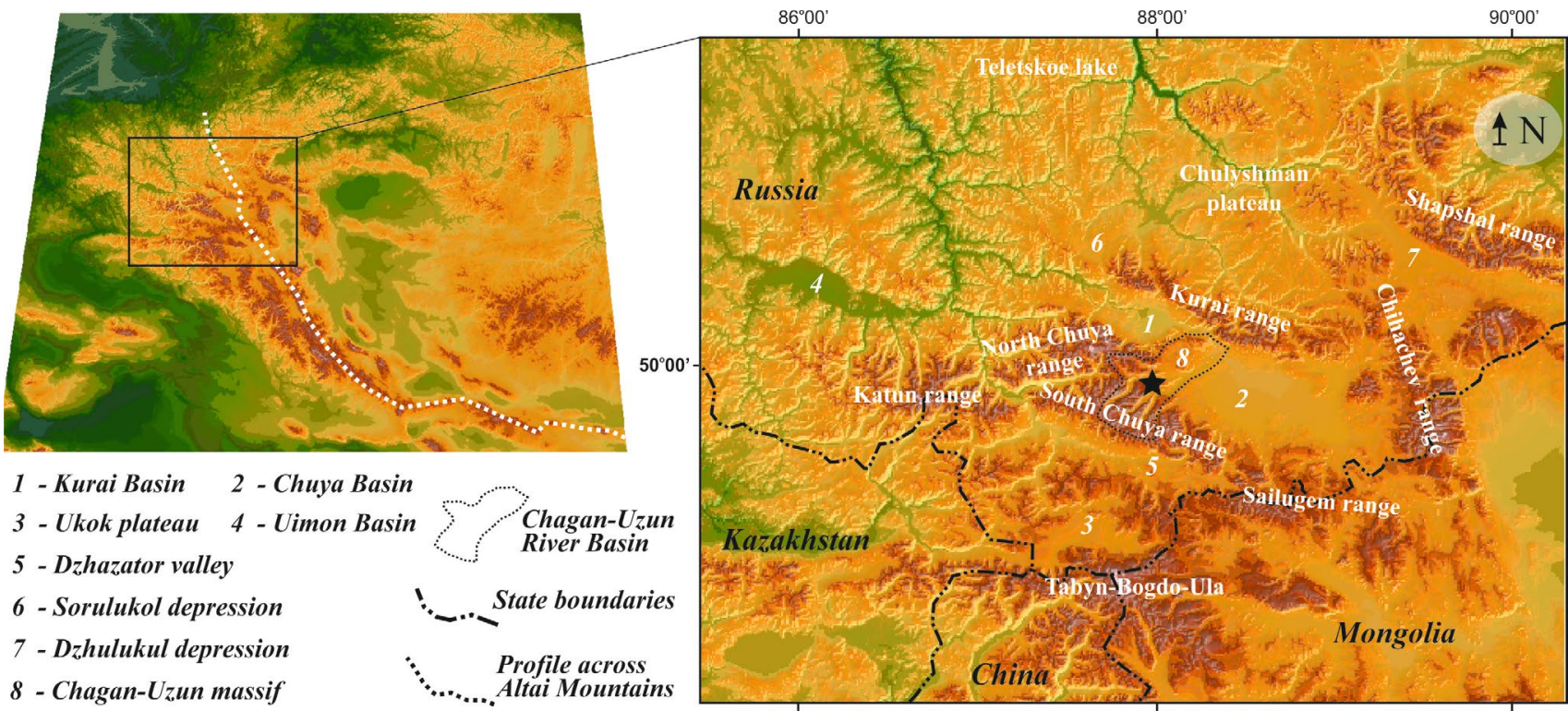

Fig. 3. Location of the Russian Altai within the Altai Mountains. Star shows the location of the Chagan section. 
1) NE Altai, Lake Teletskoe area. There is Earth crust extension in this part of the Altai Cenozoic uplift (Novikov et al., 2004). Due to the graben of the Teletskoe Lake this area is characterized by significant difference in altitudes between summit (2000-2500 $\mathrm{m}$ a.s.1.) and socle surfaces: up to $1900-2200 \mathrm{~m}$, with the lowest (for the whole Altai Mountains) altitude of the last one: about $250 \mathrm{~m}$ a.s.l. (average altitude of the lake bottom). Within mountain framing of the Teletskoe Lake tectonically driven topography roughness does not exceed 1000-1500 m. During the interglacial period in middle-late Pleistocene this area was affected by significantly lower tectonic uplifting (or even lowering) in comparison with the SE Altai. As a result, geomorphological evidence of ancient glaciations could be traced here at the lowest for the whole Altai altitudes: down to 900-1200 m a.s.l. (Agatova, 2005a). Besides the tectonic movements, moraines location at such low altitudes can be also explained by high precipitation in the region during the Pleistocene. Lehmkuhl et al. (2011) suggest that the Pleistocene ELA decreased here below $2000 \mathrm{~m}$ a.s.l. At about $1500-1600 \mathrm{~m}$ a.s.l. and higher the V-shaped valleys of lake tributaries are changed to U-shaped troughs with the morphologically younger kars at the heads of the valleys (Vysotsky, 2003). Nevertheless, some researches suppose that in the Middle Pleistocene (Svitoch et al., 1978 and Okishev, 1987, 2011) or in the end of the Late Pleistocene (Rudoy, 2013) the Lake depression was occupied by Teletsko-Chulyshman glacier with its feeding area located southward within the Chulyshman plateau. Baryshnikov (1992) supposes that the late Pleistocene glacier occupied only the northern part of the Teletskoe Lake depression and dammed ice melt water coming from the Chulyshman plateau. Further glaciers degradation triggered outburst flooding and lake drying at about $37.5 \mathrm{ka} \mathrm{BP}$, which argue for maximal glacier advance in the area during MIS 4 early MIS 3 (Baryshnikov et al., 2015). In river bank outcrops here Butvilovsky et al. (1996) distinguished evidence of four ancient glaciations - one occurred before the Pleistocene, one in the early Pleistocene and two others in the late Pleistocene (MIS 4 and MIS 2).

2) Chulyshman plateau, Sorulukol and Dzhulukul intermountain depressions (southern border of this area partly goes along the crest of the Kurai range). This area belongs to dextral strike-slip fault zone (Novikov et al., 2004) and is located on the steep slope of the socle surface with the altitude of about $500 \mathrm{~m}$ a.s.l. on the north up to $1800-2200 \mathrm{~m}$ a.s.l. on the south and 2200-2300 on the south-east. The tectonically driven topography roughness decreases in the same direction from 2000-2500 to 1000-1500 m, while altitudes of summit surfaces reach 2250-2300 in Sorulukol depression and 2800-3100 m a.s.l. in
Chulyshman plateau. Development of mainly icesheet Late Pleistocene (Efimtcev, 1961; Devyatkin, 1965; Butvilovsky, 1993; Rudoy, 1995 and Lehmkuhl et al., 2011) and, probably, Middle Pleistocene (Okishev, 1982) glaciations in the region was controlled by relatively high precipitation level and low roughness of topography (Agatova, 2005a). The depth of the erosion incision during the interglacial period was about $100 \mathrm{~m}$ (Efimtcev, 1961). During the period of maximal development of the last icesheet glaciation ice flowed radially from several peaks, sometimes crossing the watersheds, while during the period of glacial degradation ice flow was controlled by valleys and local depressions (Butvilovsky et al., 1991 and Rusanov, 2009). Northern and northwestern direction of ice flow was determined by general inclination of the socle surface within this tectonic step. The last (MIS 2, Sartan according to the Siberia stratigraphic scale) from all Pleistocene glaciations is considered by most of researches as reasonably supported by absolute (radiocarbon and OSL) dates. At the same time, presence of erratic boulders and pebbles in brownish alluvium under moraines in some sections within northern slopes of the Kurai range suggests the existence of more old glaciation (Butvilovsky et al., 1991 and Butvilovsky, 1993). Most likely in this part of Russian Altai, which is characterized by relatively weakly dissected topography, glaciers during different Pleistocene glaciation epochs occupied practically the same area, and, therefore, mainly the surface effects of the last one could be detected in topography.

3) SE Altai, the Kurai-Chuya system of intermountain depressions and framing ridges except the Sailugem range (southern border of this area goes along the crests of the South-Chuya and Katun ranges). This is a transpressional zone formed due to oblique thrusting. It is located on the brow of the socle surface with an altitude of about 1500 on the west (Kurai depression) to $2000 \mathrm{~m}$ a.s.l. on the east (Chuya depression). The tectonically driven topography roughness is about $2600-3000 \mathrm{~m}$ with the maximal value about $3500 \mathrm{~m}$ within the Katun range. This is the largest value for the whole Altai Mountains. In spite of arid climate, due to the high altitudes of the ridges (up to $4506 \mathrm{~m}$ a.s.1.) the SE Altai is the centre of the modern glaciation. Geomorphologically distinct moraines of the maximal Middle- and two Late Pleistocene (Early Zyryanka (MIS 4) and Sartan (MIS 2)) glaciations are marked out here, last of which (Sartan) was the smallest one (Devyatkin, 1965; Okishev, 1982; Agatova, 2005b; Zol'nikov et al., 2010 and others). Troughs of the younger Pleistocene valley glaciation are cut into the troughs of the older valley and piedmont glaciation to about $500 \mathrm{~m}$ which is explained by uplifting and widening of the ridges by involving the peripheral parts of intermountain depressions into 
tectonic movements during the interglacial period (Agatova, 2005a, 2005b). Particularly in this part of the Russian Altai surface effects of different glaciations could be clearly distinguished in topography due to significant relief rebuilding during the interglacial period. Moraines on the watersheds, in intermountain depressions and in the valleys are confidently distinguished by their state of preservation. It could be adopted at least two main Pleistocene glaciation epochs for the SE Altai where there were sufficient altitudes for glaciers formation already in the Middle Pleistocene in contrast to other parts of the Russian Altai. Possibly the SE Altai is only area within the Altai Mountains system where this scenario was realized.

The presence of early Pleistocene glaciation within the SE Altai was suggested by (Svitoch et al., 1978) on the basis of first TL dates from the Chagan section, located at the northern foot of the South Chuya range, and by (Zykin et al., 2016) on the basis of finds of glacial boulders in brownish alluvial deposits under moraines within the southern slopes of the Kurai range. Analyzing OSL dates of glaciolacustrine deposits in the Uimon intermountain depression, Zol'nikov et al. (2016) suppose MIS-5 stage (90-100 ka) for ice-dammed lakes formation there during Last Glacial Maximum. OSL ages of silt on the top of terminal moraines and in-between till deposits allowed Lehmkuhl et al. (2007) to date the last major ice advance in the SE Altai between 28 and $24 \mathrm{ka}$. Based on terrestrial cosmogenic nuclide dates of moraines in the Chagan-Uzun valley, Gribenski et al. (2016) suggested the Last Glacial Maximum in the SE Altai to be occurred about 17$19 \mathrm{ka}$. Associated with the glacial degradation final draining of ice-dammed lakes in the Chuya and $\mathrm{Ku}-$ rai intermountain depressions (Butvilovsky, 1993; Rudoy, 1995; Carling et al., 2002 and Herget, 2005) took place about $15.8 \pm 1.8 \mathrm{ka}$, as it is evidenced by terrestrial cosmogenic nuclide dating (Reuther et al., 2006). The development of the Sartan ice-sheet glaciation within the framing ridges of the Chuya basin about 14 ka BP (Rudoy, 2005) does not confirmed by radiocarbon age of paleopeat in the Chikhachev range (Agatova et al., 2016).

4) South Altai, the South Altai and Sailugem ranges, the Ukok plateau (southern border of this area goes along the Tabyn-Bogdo-Ula range which is affected by modern glaciation). Socle surface of the main weakly dissected tectonic blocks and intermountain depressions lies at an altitude of about 1800-2300 m a.s.l., and summit surface - at about $3000 \mathrm{~m}$ a.s.l. Altitudes of the Tabyn-Bogdo-Ula range are 3200$3400 \mathrm{~m}$ a.s.l. with the highest peak at $4374 \mathrm{~m}$ a.s.l. That is an area of the Late Pleistocene low mobile valley glaciers and ice caps (Sailugem range) (Rudoy and Kirjanova, 1996; Galakhov and Samoylova,
2007) and ice reservoirs (high mountain depressions within Ukok plateau and Dzhazator tectonic valley, which took the glaciers from Tabyn-Bogdo-Ula and South Chuya ranges) (Okishev, 1982; Butvilovsky, 1993; Rudoy et al., 2000 and Derevyanko and Molodin, 2000). Geomorphological effects of older glaciations were not detected in the topography of this area.

This analysis indicates that SE Altai is the most perspective aria for studying the chronology of the Pleistocene glaciations.

\section{Location of study site}

The Chagan-Uzun river basin (Fig. 3) is located in the SE Altai and includes southwestern part of the Chuya intermountain depression and framing ridges. Tributaries of the Chagan-Uzun river are originated in the highest parts of the North and South Chuya ranges and in the flattened top of the Chagan-Uzun massif, which separates the Kurai and Chuya intermountain depressions.

Flower structure (Cunningham et al., 1996) is the dominant fundamental structure upon which the ranges of the SE Altai are constructed as a result of oblique thrusting (Novikov, 2004). Northern gentle and elongated slope of the South Chuya range consists of several tectonic steps and peripheral parts of the Chuya intermountain depression are involved into uplifting. One of the transverse tectonic riegels crosses the Chagan and Taldura valleys (up to $50 \mathrm{~m}$ in the Chagan valley). It controlled the Pleistocene glaciers development in these valleys (Ivanovsky, 1956 and Agatova, 2003).

Mapping accumulation surfaces of glacial origin within study area (Agatova, 2005b) revealed i) younger stadial moraine ramparts in valleys up to the nearest to modern glaciers LIA moraines; ii) two complexes (proximal and peripheral) of well-expressed terminal and lateral moraines in the Chuya depression; and iii) the oldest smoothed moraine cover partly preserved at watersheds on the lower tectonic steps of the range and in the intermountain depression outside the well-expressed peripheral moraine complex (Fig. 4). In the upper part of the Chagan-Uzun river basin younger glacial landforms are embedded into the older ones while they cover the older glacial landforms in the down part of the basin. Lateral moraines of both Taldura and Chagan peripheral moraine complexes merge on the Taldura-Chagan watershed at about $2600 \mathrm{~m}$ a.s.l. Studying denudation surfaces of glacial origin discovered a system of imbedded troughs including up to three generations, which could be correlated with accumulative glacial landforms.

We suppose that washed and eroded remnants of the moraine covering outside the well-expressed terminal moraines on tectonic steps of the South Chuya range and in the Chuya depression are the traces of one (or possibly several) of the ancient piedmont glaciations. Complex of well-preserved moraines argue for valley type of the next glaciation. Stadial ramparts of the proximal moraine 
complex are younger because they are imbedded into moraines of the peripheral complex or cover them. Among all glacial landforms, moraines in the valleys are the youngest ones. Once again, the question of using them for reconstructing independent glaciation is open. Lack of geochronological data makes it difficult to determine the age of moraines except the nearest to the modern glacier LIA $\left(13^{\text {th }}-19^{\text {th }}\right.$ centuries $)$ moraines (Agatova et al., 2012).
Therefore, different geomorphological features of various moraine complexes and their different state of preservation argue for at least of two ancient glaciations within the SE Altai. Most likely they were separated by prolonged interglacial period when due to tectonic activity the valleys of the South Chuya range were deepened.

Following the established traditional concept of the Russian Altai Quaternary geology (Devyatkin, 1965; Ivanovsky, 1967; Popov, 1972 and Okishev, 1982) we
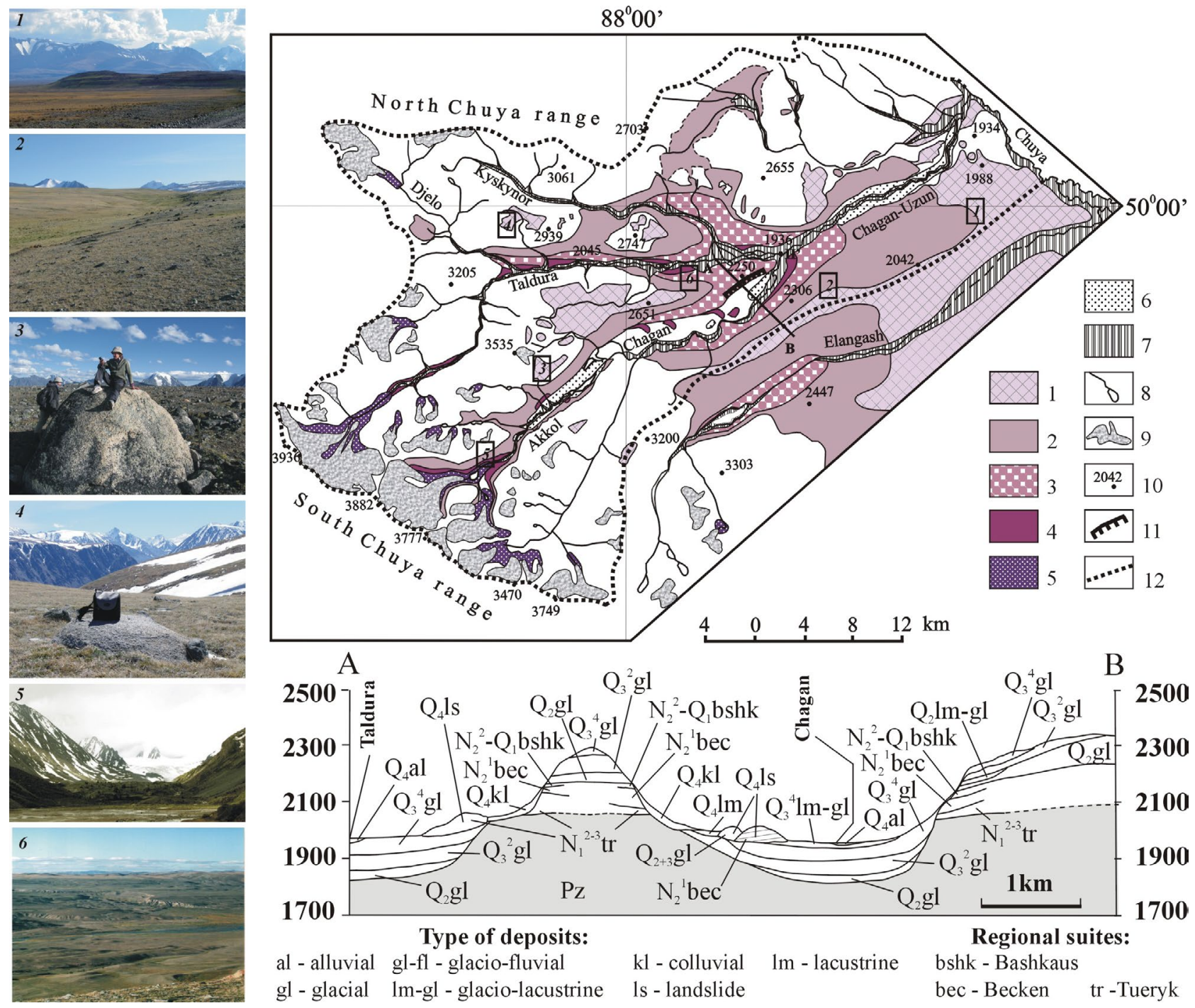

Fig. 4. Spatial distribution of glacial landforms and sediments of different states of preservation within the Chagan-Uzun massif. The cross-section across the Taldura-Chagan watershed $(A-B)$ is shown below. Deposits of Miocene and Pliocene epochs are indexed as $\mathrm{N}_{1}{ }^{1-3}$ and $\mathrm{N}_{2}{ }^{1-2}$ correspondingly, and Pleistocene - as Q1-3 according to Stratigraphic Code of Russia (Zhamoida, 2006). Taking into account the lack of reliable absolute dates we follow the traditional Russian scheme of relative ages of ancient glaciations within the Russian Altai (Devyatkin, 1965; Okishev, 1982), where Q4 indicates the Holocene glacier advances, $Q_{3}$ is associated with the late Pleistocene (Würm according Alpine scheme) including $Q_{3}{ }^{2}$ and $Q_{3}{ }^{4}-$ Zyryanka and Sartan stages according Siberian stratigraphic scheme correspondingly, and $Q_{2}$ - middle Pleistocene (Riss according Alpine scheme). 1 - flattened and washed moraines, partly covered by sub-aerial cryogenic loams $\left(Q_{2}\right.$ ?); 2 - distal complex of well-preserved terminal and side moraines within Chuya depression, ( $Q_{3}{ }^{2}$ ?); 3 - proximal complex of well-preserved terminal and side moraines, (Q ${ }_{3}{ }^{4}$ ?); 4 - late Pleistocene - Holocene moraine ramparts of different glacial stages within river valleys, $\left(Q_{3}{ }^{4}\right) ; 5-L I A$ moraines, $\left(Q_{4}\right) ; 6$ - glacial-lacustrine sediments of different ages; 7 - alluvial deposits; 8 - lakes and rivers; 9 - glaciers; 10 - altitudes (m a.s.l.); 11 - Chagan section; 12 - Chagan-Uzun River bounders. A-B - location of the cross-section across the Taldura-Chagan watershed.

Photos demonstrate moraines of different state of preservation and their locations (number in rectangle) within the basin. 
refer well preserved ramparts of proximal and peripheral moraine complexes to the Late Pleistocene glaciation, and washed and eroded remnants of moraine cover beyond these complexes - to the Middle Pleistocene glaciation. Thus, assuming these glacial sediments in the Chuya depression and at the watersheds on the lower tectonic steps of the South Chuya range belong to a single glaciation, in transitional zones where younger sediments cover the older ones, we can expect moraine complexes at least of two glaciations to be exposed in proximal outcrops including the presented here Chagan section.

\section{Chagan Section: description and available data}

The Chagan section, located in the transition zone between the Chuya intermountain depression and South Chuya range (Fig. 4), is one of the reference sections of the Pleistocene glacial, glacio-fluvial, and glaciolacustrine deposits in the region. This section is about $4 \mathrm{~km}$ long and $\sim 200 \mathrm{~m}$ high containing several units (Fig. 5). Interaction of the Chagan and Taldura glaciers in the area of their conjunction determines the structural complexity of glacial thickness here. In the Chagan river valley lateral ramparts of the proximal moraine complex within the upstream part of the section are at about $2250 \mathrm{~m}$ a.s.l. Downstream the altitude of the section increases due to overlaying lateral moraines of the Taldura glacier.

Preglacial deposits at the bottom of the section have Low Neogene - Low Pleistocene ages (Devyatkin, 1965 and Rusanov, 2011). They include light gray and yellowish-gray lacustrine sediments of the Tueryk suite, yellowish-brown lacustrine-alluvial sediments of the Beken suite, and brown-reddish alluvial sediments of the Bashkaus suite. We have also explored sediments of the Tueryk suite (middle Miocene - middle Pliocene) in structure of the Chagan-Taldura watershed when studying the giant landslide triggered by the 2003 Chuya earthquake $\left(M_{S}=7.3\right)$ opposite the Chagan section in Taldura river valley (Fig. 4) (Agatova et al., 2004).

Overlying glacial deposits have a basal thin (1.5$7.0 \mathrm{~m}$ ) moraine layer with brownish redeposited sediments of the Bashkaus suite.

Above it there is a lens (up to $45-50 \mathrm{~m}$ ) of light gray fine-grained glacio-lacustrine sediments with drop-stones and layers with carbonate concretions (up to $10-15 \mathrm{~cm}$ in diameter) at the unit boundaries. Svitoch et al. (1978) and Butvilovsky (1993) suggested the duration of this lens accumulation about 130-150 years. Some researchers believe that it was a periglacial lake at the glacier margin (Glushankova and Voskresenskaja, 2008) or morainedammed lake (Sheinkman, 1990), whilst others think that these sediments fill the paleo river channel produced in Bashkaus pebbles (Rusanov, 2011). This paleochannel stretches along the foot of the South Chuya range i.e. across the modern Chagan-Taldura watershed and across the Chagan section. Rusanov (2011) supposes that the lacustrine sediments of this lens were accumulated in the narrow bay of the Pleistocene ice-dammed lake in the Chuya depression. When studying the surface effects of the 2003 Chuya earthquake we did not find any evidence of the possible continuation of this channel (lake bay) at the opposite side of the Chagan-Taldura watershed in the main scarp of giant seismically induced landslide in the Taldura river valley.

Above the lens there is a thick (about $60-80 \mathrm{~m}$ ) gravel-dominated section of gray moraine and glacio-fluvial sediments with distinct sandy layers of fluvial origin. The glacial deposits are characterized by a high degree of facies variability, which cause difficulties in distinguishing the different glacial episodes. Before the 2003 Chuya earthquake two clearly distinguished steps were formed as a result of long-term erosion. Devyatkin (1965) interpreted them as evidence of two different glaciations but it could be also explained by different resistance of strata to erosion. Borisov (1984) and Butvilovsky et al. (1996) establish five separate glacial events in this section but these reconstructions are not correlated with each other.

The top of the exposure has a height of $2250 \mathrm{~m}$ a.s.1., which coincides with the possible maximum filling of the Pleistocene ice-dammed palaeolakes in the Chuya depression (Rusanov, 2008). The timing of formation and the outburst events of these giant lakes is still debated, however, the preservation of high lake terraces here argues for moraines formation before the maximum occupancy of the lake. Thus, the age of the largest icedammed palaeolake could be assumed as an upper possi-
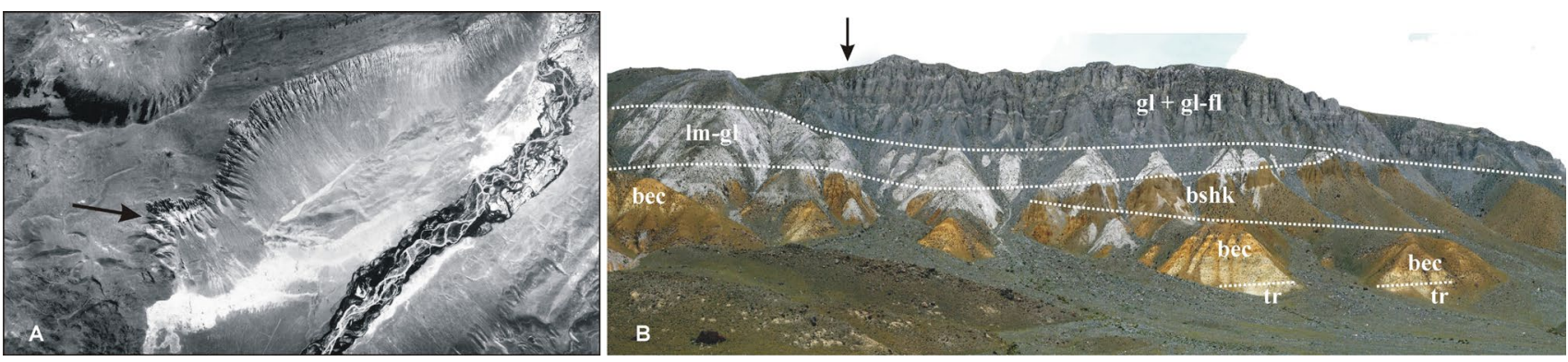

Fig. 5. Chagan section - the regional reference sections of the Pleistocene glacial, glacio-fluvial, and glacio-lacustrine deposits. Aerial photograph A) and common view of the section B). Arrow shows the location of the studied section (Fig.7). Regional suites and types of deposits are described in Fig.4. 
ble age of deposition processes. It could be correlated with the late Pleistocene (25-12 ka BP (Rudoy, 2005 and Rusanov, 2008)) or, in contrast, with the middle Pleistocene (Zol'nikov and Mistrukov, 2008). We assume the formation of the Chagan section as a result of lake abrasion and seismically induced landsliding. The entire Chagan section was exposed by repeated earthquaketriggered landslides. Seismic origin of this multikilometers outcrop in permafrost rocks was confirmed during the 2003 Chuya earthquake. A number of new seismo-gravitational cracks were developed along the brow of the valley slope. High seismicity during the accumulation of sediments in this section is evidenced by numerous seismically induced disturbances: seismic convolutions, cracks and offsets (Agatova et al., 2006). Some landslides, composed of Bashkaus alluvial pebbles and covered by thin washed moraine, were erroneously taken as moraines of the Akkem glacial stage (one of the Late Pleistocene stages of glaciers advances in the SE Altai) by Borisov (1984), but this interpretation is adopted in the Russian Altai stratigraphic scheme.

Paleomagnetic characteristics of the Chagan section argue for two short-term episodes of magnetic polarity reversals for glacial part of this section (Faustov et al., 1971 and Svitoch et al., 1978). One of them, Chagan episode, corresponds to the lens of glacio-lacustrine deposits and has TL age $266 \pm 30 \mathrm{ka}$. The second one, correlated with Blake geomagnetic polarity episode, has TL age $145 \pm 13 \mathrm{ka}$. It was established for glacial deposits at the depth of about $20-45 \mathrm{~m}$ and probably could serve as a reference layer for age distinguishing of moraines. At the same time, as it was mentioned by (Svitoch et al., 1978), correlation of obtained paleomagnetic zones in the Chagan section with the paleomagnetic chronological scale is very difficult. Now the age of the Chagan episode (Biva II) is assumed to be about 290 ka (Quaternary System, 2008).

First palynology studies of the Chagan section (Svitoch et al., 1978) revealed similarity of spore-pollen spectra from this section and those obtained in areas affected by modern glaciation. However, we have twice failed to detect pollen in glacial deposits of the Chagan section (Mikhailova et al., 2004). Generally due to intensive pollen transportation and redeposition, palinological analysis of glacial deposits is not informative and should cautiously be used only in complex with other techniques.

There are also only single paleontological finds in this section (Mikhailova et al., 2004 and Rusanov and Vazhov, 2014). Generally, all applied geological and geophysical methods did not allow making chronological distinguishing of glacial sedimentation in the Chagan section.

The first absolute dates for the Chagan section were obtained in the late 1970s. The Early and Middle Pleistocene ages of moraine deposits from Chagan section were based on three TL dates $-145 \pm 13,266 \pm 30$ and
$476 \pm 51$ ka obtained with artificially saturated samples (Fig. 6) (Svitoch et al., 1978). They suggested the Middle Pleistocene glaciation as being the largest one whilst, in spite of more significant lowering of the snow line, the Late Pleistocene glaciation (which is not presented in the Chagan section) is thought to be just a valley glaciation. Until now these dates have formed the basis of the formal region correlation schemes for the Russian Altai (Volkova and Babushkin, 2000; Quaternary System, 2008 and Volkova et al., 2010). At the same time, all recent editions of these schemes applied a concept of Borisov (1984) as a basis. Using the same TL dates, he described much more glaciations in deposits of the Chagan section (one Early, two Middle and two Late Pleistocene glaciations, as well as tree interglacial periods).

At the end of the $20^{\text {th }}$ century there was an attempt to revise the initial TL data using a TL technique based on applying naturally saturated etalons (Sheinkman, 1990; 2002) ${ }^{2}$; however, the attempt to date the lowest glacial strata failed. Five new TL ages for the Chagan section were obtained; one sample from the upper part of the lens of glacio-lacustrine sediments which gave age $\geq 100 \mathrm{ka}$, and four from glacial deposits in the upper part of the section which fell into the range of values $58 \pm 7$ $85 \pm 11$ ka (Fig. 6). Three more TL dates $(81 \pm 10$, $121 \pm 14$, and $135 \pm 15 \mathrm{ka}$ ) were obtained from another separate outcrop located $3 \mathrm{~km}$ upstream the Chagan river (see Discussion for comments). Sheinkman (2002) proposed a Late Pleistocene age for these glacial sediments and believed the Late Pleistocene glaciation being the largest one within the Russian Altai.

There are also three radiocarbon dates of carbonate concretions from the glacio-lacustrine lens at the bottom of the glacial part of the section and from thin glaciolacustrine layers in its middle part (Fig. 6). They were obtained by Butvilovsky (Rusanov and Orlova, 2013). Radiocarbon samples have an inverse stratigraphic position in the section (the older samples are located above the younger ones) and their ages have another order of magnitude in comparison with the TL data. These dates fall into the Sartan glaciation (the end of the Late Pleistocene).

Rusanov (2011) marks out two units in the glacial part of the Chagan section. The low unit includes the basal moraine and glacio-lacustrine lens when the upper one is the single gray-colored unit of about $100 \mathrm{~m}$ thick. With the azimuthal unconformity the upper unit overlays the eroded surface of the lens and alluvial gravels of the Bashkaus suite. At the bottom of this upper gray-colored unit a single paleontological find (heavily damaged sec-

\footnotetext{
${ }^{2}$ Sheinkman (1990) presented four dates from the upper part of the section and boundary date ( $\geq 300 \mathrm{ka}$, complete saturation) for the underlying reddish alluvial sediments at the bottom of the glacial part of the section. Later (Sheinkman, 2002) two of these ages were recalculated and location for these samples were specified as well as the TL age $\geq 100 \mathrm{ka}$ for glacial-lacustrine lens was presented. Our comments to these data are given as a footnote in Fig. 6.
} 


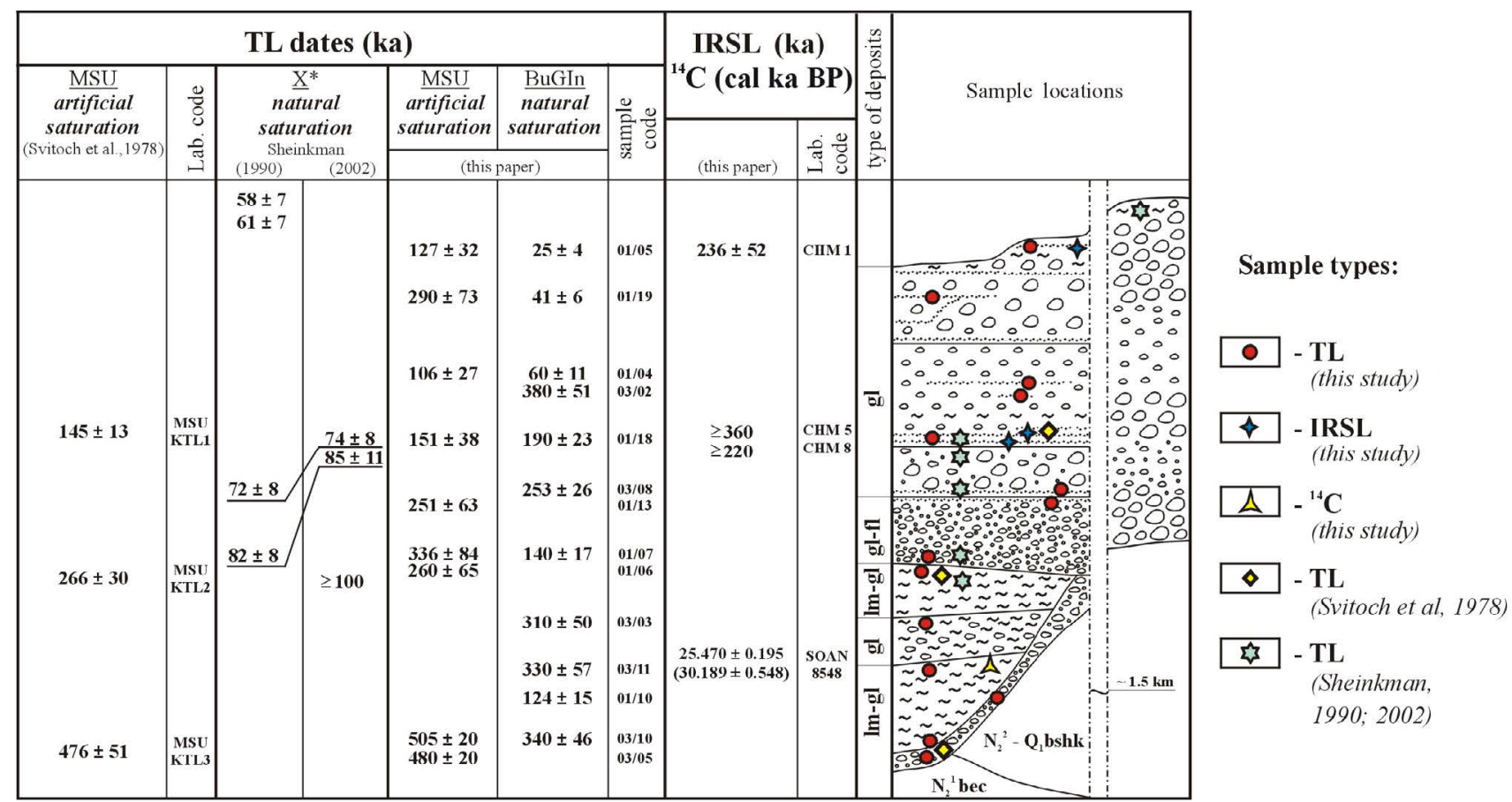

Fig. 6. Correlation scheme of absolute dates for glacial sediments from Chagan section obtained by different authors. Designation of deposition units is given in Fig. 7.

* No information about both the dating laboratory and sample codes was presented by the author. First mention about these dates was given in 90th of the last century (Sheinkman, 1990, P.81). Twelve years later these dates were recalculated (Sheinkman, 2002, P.45, 46) (without any explanations of methodology or the reasons) and their position in the section was specified (underlined dates). This could not allow utilising these data as the "new generation dates", as they were presented in (Zol'nikov and Mistrukov, 2008 and Rusanov, 2011).

tion of the upper tooth - Equus sp., presumably of the late Pleistocene age) was discovered by Rusanov (2011) and he suggests the Late Pleistocene age for the whole upper $100 \mathrm{~m}$ unit.

The significant discrepancy between TL dates based on different techniques as well as their disagreement with radiocarbon dates prompted us to carry out our own investigation of glacial and associated sediments of the Chagan section including applying different absolute dating techniques (radiocarbon, TL and OSL methods).

\section{ABSOLUTE DATING OF GLACIAL AND AS- SOCIATED SEDIMENTS FROM THE CHAGAN SECTION}

\section{Radiocarbon dating}

A single sample for radiocarbon analysis was collected from carbonate concretions in glacio-lacustrine lens located at the bottom of the glacial part of the section above the brownish sediments of Bashkaus suite (Fig. 7).

Sample preparation and radiocarbon age measurement was made at the Institute of Geology and Mineralogy SB RAS, Novosibirsk. The determination of carbon residual activity was done with the QUANTULUS-1220. The conventional radiocarbon age was calibrated (2-sigma standard deviation) applying the CALIB Rev 5.0 program
(Stuiver and Reimer, 1993), with the IntCal09 calibration data set (Reimer et al., 2009).

The calculated age $(30189 \pm 548$ cal. BP; SOAN 8548 (Table 1)) correlates with the other available radiocarbon data previously obtained at the same laboratory by Butvilovsky (Rusanov and Orlova, 2013).

\section{Luminescence dating}

\section{Sampling strategy}

Insufficient bleaching of glacial sediments is a common problem for making adequate luminescence dating (Fuchs and Owen, 2008). Deposits associated with proglacial, glacio-fluvial and glacio-lacustrine sediments have a higher potential to be bleached than subglacial and englacial ones, but the risk of insufficient bleaching is still considerable. For example, glacio-fluvial sediments may not be fully exposed to daylight due to the turbidity in the meltwater or attenuation of the daylight intensity with depth. Modern glacio-fluvial samples have been shown to exhibit residual luminescence signals which lead to overestimation of the calculated ages (Gemmell, 1997; 1999). Essentially, the effectiveness of luminescence signal zeroing is directly controlled by the geomorphic processes responsible for the sediment production and reworking. Thus, a geomorphological under 


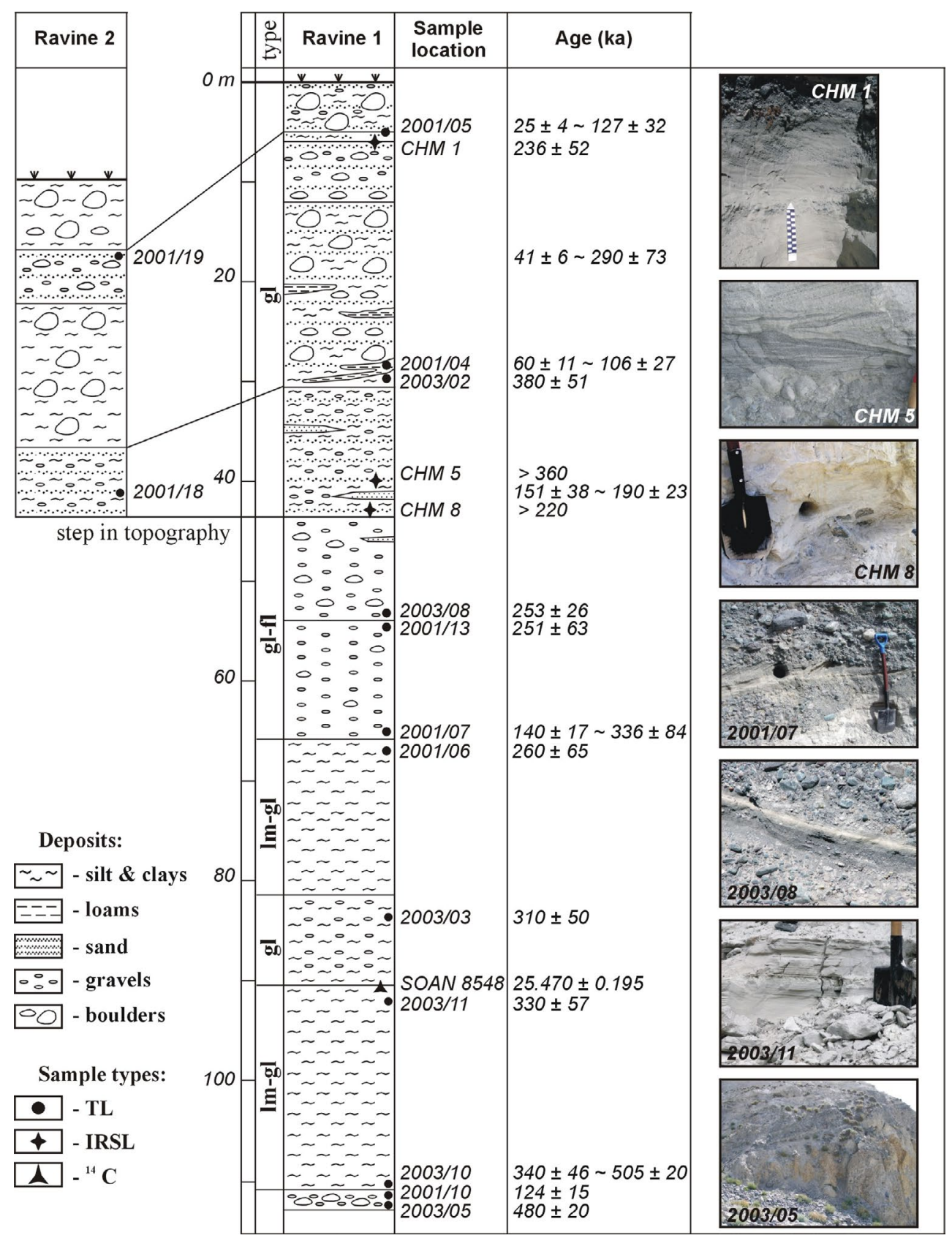

Fig. 7. New absolute dates of glacial and associated sediments from the Chagan section.

standing of the glacial environment is required to identifysediments and the association with the particular geomorphological process in the context of sufficient intensity and duration of daylight exposure.

Prior to sample collecting, detailed geomorphological investigations of the Chaga-Uzun river basin were carried out in order to determine the number, patterns of and evolution of the Pleistocene glaciations in the region.

The identification of appropriate sediments for luminescence dating, as well as samples collection, was done following recommendations and suggestions of Richards (2000) and later of Benn and Owen (2002). The material for luminescence dating was derived from glacio-fluvial, glacio-lacustrine and englacial meltwater sediments to estimate the age of moraine formation equal to the age of glaciations. Several samples were collected from alluvial deposits of the Bashkaus suite, which underlies the Pleistocene complex of glacial deposits in the Chagan section, to estimate the lowest possible age of glaciations. Preference was given to deposits containing finely grained fractions. During the later field researches in situ doserate measurements were carried out by portable gamma ray spectrometer. 
Table 1. Obtained absolute dates.

Applied techniques: RTL - radiotermoluminescence; IRSL - Infra Red stimulated luminescence; ${ }^{14} \mathrm{C}$ - scintillation radiocarbon analysis

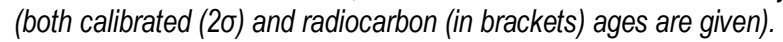

\begin{tabular}{|c|c|c|c|c|}
\hline$\overline{\mathbf{N}}$ & Sample & Lab. code & Technique & Age (ka) \\
\hline \multirow{2}{*}{1} & \multirow{2}{*}{$2001 / 04$} & BuGIN 504 & RTL & $60 \pm 11$ \\
\hline & & MSU NS-4 & RTL & $106 \pm 27$ \\
\hline \multirow{2}{*}{2} & \multirow{2}{*}{$2001 / 05$} & BuGIN 498 & RTL & $25 \pm 4$ \\
\hline & & MSU NS-5 & RTL & $127 \pm 32$ \\
\hline 3 & $2001 / 06$ & MSU NS-6 & RTL & $260 \pm 65$ \\
\hline \multirow{2}{*}{4} & \multirow{2}{*}{ 2001/07 } & BuGIN 503 & RTL & $140 \pm 17$ \\
\hline & & MSU NS-7 & RTL & $336 \pm 84$ \\
\hline 5 & $2001 / 10$ & BuGIN 501 & RTL & $124 \pm 15$ \\
\hline 6 & $2001 / 13$ & MSU NS-13 & RTL & $251 \pm 63$ \\
\hline \multirow{2}{*}{7} & \multirow{2}{*}{ 2001/18 } & MSU NS-18 & RTL & $151 \pm 38$ \\
\hline & & BuGIN 506 & RTL & $190 \pm 23$ \\
\hline \multirow{2}{*}{8} & \multirow{2}{*}{$2001 / 19$} & BuGIN 513 & RTL & $41 \pm 6$ \\
\hline & & MSU NS-19 & RTL & $290 \pm 73$ \\
\hline 9 & $2003 / 02$ & BuGIN 664 & RTL & $380 \pm 51$ \\
\hline 10 & $2003 / 03$ & BuGIN 665 & RTL & $310 \pm 50$ \\
\hline 11 & $2003 / 05$ & MSU NS-305 & RTL & $480 \pm 20$ \\
\hline 12 & $2003 / 08$ & BuGIN 669 & RTL & $253 \pm 26$ \\
\hline \multirow{2}{*}{13} & \multirow{2}{*}{$2003 / 10$} & BuGIN 670 & RTL & $340 \pm 46$ \\
\hline & & MSU NS-310 & RTL & $505 \pm 20$ \\
\hline 14 & $2003 / 11$ & BuGIN 671 & RTL & $330 \pm 57$ \\
\hline 15 & & CHM1 & IRSL & $236 \pm 52$ \\
\hline 16 & & CHM5 & IRSL & $\geq 360$ \\
\hline 17 & & CHM8 & IRSL & $\geq 220$ \\
\hline 18 & & OAN 8548 & ${ }^{14} \mathrm{C}$ & $\begin{array}{c}c 30.189 \pm 0.548 \\
(25.470 \pm 0.195)\end{array}$ \\
\hline
\end{tabular}

\section{Thermoluminescence dating}

TL method was used prior to the development of OSL and IRSL methods. Previously, the applicability of TL dating has been demonstrated for various sedimentary environments (Wagner, 1998 and references therein), mainly focused on those that have experienced sufficient exposure to daylight enabling a complete resetting of the luminescence signal. Luminescence dating of glacial and associated sediments is difficult, mainly due to insufficient bleaching during transportation and deposition of the sediments (Fuchs and Owen, 2008 and references therein).

In addition to the problem of zeroing of the luminescence signal, there is also a great regional diversity in physical properties of quartz grains. Quartz properties, with regards to their luminescence signal, are mainly determined by the content and composition of microimpurities which form electron traps in the mineral crystal structure. This leads to variations in the suitability of a quartz or alternative silicate minerals (such as feldspar) as a geochronometer for luminescence dating.

Generally 38 samples were collected from deposits containing sands and sandy loams within the Chagan section. Luminescence sample preparation was carried out under subdued red light applying standard chemical treatment including clay fraction washing and wet sieving
$(0.10-0.25 \mathrm{~mm})$, hydrochloric and hydrofluoric acid etching, ultrasonic grinding with further sieving (0.1 $\mathrm{mm}$ ), and separation of the light fraction in bromoform. Thermoluminescence dating was carried out in two laboratories which applied different radiothermoluminescence (RTL) methods. The RTL dating technique with the artificially saturated standard (Vlasov and Kulikov, 1989) was applied in the Laboratory of dosimetry, radioactivity and RTL dating, Moscow State University (MSU), while RTL age determination using naturally saturated standard (Shlukov et al., 1997 and Perevalov and Rezanov, 1997) was utilized in the RTL dating Laboratory, Buryatia Geological Institute SB RAS (BuGIN). Considering the problems associated with the applying of luminescence methods for dating glacial and associated sediments, as well as the complexity of the samples used for testing these techniques, we sent five samples to both laboratories.

20 new RTL dates are presented in table (Table 1, Fig. 7). Among all studied samples there were three naturally saturated ones, which is crucial for age measurement when applying the RTL technique on the basis of naturally saturated etalons (Shlukov et al., 1997).

11 BuGIN RTL dates (obtained with the naturally saturated etalon) indicate accumulation of glacial deposits in the Chagan section between $25 \pm 4-380 \pm 51$ ka while nine MSU RTL dates (obtained with the artificially saturated standard) define this time interval as $106 \pm 27-$ $505 \pm 20 \mathrm{ka}$. At the same time four among five samples dated in both laboratories return different ages. Moreover, there is a discrepancy with the stratigraphic position for samples dated in both laboratories. The highest correlation amongst all dates is observed for the lens of glaciolacustrine sediments. Five dates are in the range of 260 $340 \mathrm{ka}$ (the Middle Pleistocene) and only one (obtained in MSU as $505 \pm 20 \mathrm{ka}$, which was also dated in BuGIN as $330 \pm 57 \mathrm{ka}$ ) stands out.

It is noteworthy that in the samples analyzed at BuGIN, from the 24 successfully prepared samples a TL signal was measured only from 14 samples, including the 3 saturated ones. Quartz extracted from the remaining ten samples gave powerful low temperature peak and therefore was unsuitable for measurements. A similar proportion of undated samples came from MSU laboratory. This fact, once, emphasizes the importance of the discussion about choosing the mineral-paleodosimeter (quartz versus feldspar) for regional luminescence dating.

\section{OSL dating}

The optically stimulated luminescence (OSL) method is expected to be more suitable for dating glacial sediments, mainly due to the significantly shorter time (several seconds) of daylight exposure needed for complete bleaching the sample. In 2008 we made a first attempt to apply this technique for dating deposits of glacial origin from the Chagan section. A number of samples were taken from the glacio-fluvial and glacio-lacustrine layers. It was discovered that quartz in these samples showed a 
strong response to IR stimulation, thought to be resulting from feldspar present as inclusions, and therefore feldspar had to be used for analysis although it is only present in very low quantities.

Initial tests on the IRSL signal obtained at $50^{\circ} \mathrm{C}$ stimulation temperature demonstrated relatively high De values $(>300 \mathrm{~Gy})$ and fading rates of up to $7 \%$. This combination of a large natural De and high fading rates led to problems when applying a fading correction, as the corrected De value falls on the "flatter" part of the doseresponse curve near/in saturation. For age estimation of the samples, the post-IR IRSL dating procedure (Thomsen et al., 2008 and Buylaert et al., 2009) was applied using IR stimulation temperatures of $50^{\circ} \mathrm{C}$ and $225^{\circ} \mathrm{C}$. Using this protocol, a number of the older samples had a post-IR IRSL De value in saturation, and typical fading rates of between 0 and $2 \%$ were measured (Agatova et al., 2014). Applying the fading correction to the De values obtained from both the $50^{\circ} \mathrm{C}$ IRSL and post-IR IRSL signal resulted in similar De values where the results were not in saturation. Additionally, the residual doses in both the $50^{\circ} \mathrm{C}$ IRSL and post-IR IRSL were measured following sunlight bleaching of untreated discs from sample CHM1 (uncorrected De of $\sim 300$ Gy) and appeared to reach a plateau of $\sim 5$ Gy and $\sim 20$ Gy, respectively, after 1 hour.

Applying this technique 3 absolute dates were obtained in Institute for Geology and Palaeontology, University of Innsbruck, Austria (Fig. 7). The Middle Pleistocene age (236 $\pm 52 \mathrm{ka}$ (CHM1)) of the glacio-fluvial sandy layer in the upper part of the section at $2250 \mathrm{~m}$ a.s.l. was obtained. It is older age than all previously published dates for the upper part of the section. Geochemical analysis reveals a significant difference in content of petrogenic oxides between this layer and other glacial stratums, suggesting a possible change the source area and pattern of sedimentation in the upper part of the section. A glacio-fluvial sandy layer at a depth of about $60 \mathrm{~m}$ has a Middle Pleistocene age or older $(>360 \mathrm{ka}$ (CHM3), >220 ka (CHM8)).

\section{DISCUSSION}

The numerical age estimation for deposits of the Chagan section is important for the regional stratigraphy and region correlation schemes for the Russian Altai and Siberia. At the moment, there are 4 radiocarbon ages (three previously published), 28 TL (8 previously published) ages, and 3 IRSL ages for the upper part of the section, which includes glacial sediments of various types; and 2 previously published TL dates for underlying alluvial deposits ${ }^{3}$.

\footnotetext{
${ }^{3}$ Sheinkman (2002) reported applying nanocycle (varvocycle) technique (Afanas'ev, 1990) for testing TL dates from glacial deposits of the Chagan section. At the same time this technique was suggested for lacustrine sediments of platform areas (Afanas'ev, 1990). Correlation of the lacustrine sedimentation patterns with the Earth's gravitational
}

Taking into account the physical basis of the applied luminescence techniques, OSL method is expected to be more reliable in comparison with TL. It has the advantage shorter times needed for complete bleaching of the luminescence signal, which is particularly important when dating glacial and associated sediments; it takes just a few seconds of direct sunlight exposure for the more light sensitive OSL and IRSL signals against several tens of hours for less light sensitive TL signal.

Analysis of all the available luminescence dates revealed the best correlation of results in the lens of glaciolacustrine deposits and allows to assume its Middle Pleistocene age, that, however, requires further verification.

We also argue that it is inappropriate to correlate aleuropelite layer from glacio-lacustrine deposits in the Tedesh section (TL dates $121 \pm 14$ and $135 \pm 15$ ka were reported for these sediments in (Sheinkman, 2002)) with glacio-lacustrine lens in the Chagan section, and therefore, to utilize these TL dates for absolute age estimating glacio-lacustrine deposits in the Chagan section as it was done in (Sheinkman, 2002; Zol'nikov and Mistrjukov, 2008 and Rusanov, 2011). Such geochronological correlations are not valid, regardless of the applied dating technique. Tedesh and Chagan sections are located in $3 \mathrm{~km}$ from each other and are separated by the transverse tectonic riegel crossed the Chagan valley. Slope in this part of the valley is covered by talus fans with no clear transition between these sections and glacio-lacustrine sediments of the lens wedge out at the surface of the tectonic riegel.

Good correlation of TL dates for the glacio-lacustrine lens supports the thesis that glacio-lacustrine sediments are one of the most perspective ones for luminescence dating among all glacial and associated deposits. It is likely that the sedimentation patterns in the glacial lake increased the extent of bleaching when compared to the sedimentation during subglacial and englacial processes. The possible Middle Pleistocene age of this lens also does not contradict to the results of our geomorphological investigations, which argue for presence of deposits of several glacial epochs in the Chagan section. We suppose that following researches should pay special attention to this lens in the Chagan section while making further study and testing various numerical techniques for dating glacial and associated sediments.

Generally, the large scattering of obtained TL ages and their low correlation with the stratigraphic position in the section allow us to conclude that TL method does not fit for dating glacial sediments and landforms, and cannot be used for stratigraphic breakdown, as well as for mak-

field (defined by position of the planets in the Solar system) forms the basis of this method. It is clear that in high mountain areas the glacio-lacustrine sedimentation patterns are mainly controlled by glacier runoff, proximity of the slopes and glacier itself to the lake, lake size, bottom inclination and so on. Thus we suppose that utilizing this technique for mountain areas is highly debatable, it could not be used for independent age control, and we do not analyse the nanocycle dates in this paper. 
ing any geochronological reconstructions and correlations.

The OSL technique is expected to be more suitable for dating glacial sediments. Narama et al. (2007) reported the successful application of the OSL technique for dating glacial and loess deposits in the northern flank of the Terskey-Alatoo Range, Central Asia during the Last Glacial. Material for the OSL dating (fine- and coarsegrained quartz) was collected from loess and redeposited glacial sediments with the fluvial layers at up to $2 \mathrm{~m}$ depth. Obtained OSL data were partly controlled by radiocarbon method and indicated glacier expansion between 29 and $21 \mathrm{ka}$ BP during MIS2 with the maximum glacier advances occurred at about $76 \mathrm{ka}$ BP during the MIS4. Good OSL dating results were also obtained for supraglacial meltout tills in Nepal (Tsukamoto et al., 2002), and for glacio-fluvial deposits, which included sand lenses sandwiched between tills in moraines (Zhao et al., 2013).

At the same time glacial sediments within the Russian Altai are very problematic for luminescence dating. Applying OSL dating technique for fluvial and aeolian deposits Lehmkuhl et al. (2007) show the last major glaciers advance in the Russian Altai between 28 and $24 \mathrm{ka}$ in the beginning of the last glacial cooling maximum followed by an increased rate of loess accumulation. IRSL dating approach (utilized on moraines and laminated icedammed lake sediments) yielded low signal intensities and maximum ages with large uncertainties owing to insufficient bleaching during short distance transport (Lehmkuhl et al., 2007). OSL dates of glacio-lacustrine deposits within the Chagan-Uzun river basin $5 \mathrm{~km}$ downstream the Chagan section scatter between 200 and $50 \mathrm{ka}$ and are not in stratigraphic order. Same difficulties in applying luminescence techniques for dating glaciofluvial deposits in Estonia were reported by (Raukas and Stankowski, 2005).

The small number of IRSL dates obtained does not allow us to assess the appropriateness of using this method for age estimation of glacial and associated sediments, which remain one of the most difficult types of continental deposits for dating. It also does not allow clearly determine the ages of glacial deposits in the Chagan section. We can only assume a relatively low number of depositional cycles for the grains in this section and a short transport which is also problematic for luminescence dating techniques.

Another important problem is the selection of the mineral-dosimeter and associated task of choosing the best dating technique. Among two the most commonly used minerals, quartz and feldspar, the luminescence signal from feldspar is an order of magnitude greater than for quartz (Aitken, 1998). Feldspar, however, is less rapidly bleached than quartz, sometimes by a factor of about 10 (Godfrey-Smith et al., 1988), and also suffers from the problem of anomalous fading (Aitken, 1985, 1998).

Our study revealed that strong low temperature peak in the TL signal is a regional feature of quartz from the
Chagan section. This led to failure in determining a number of TL ages. It was also discovered that regional quartz showed a strong response to IR stimulation, thought to be resulting from feldspar inclusions. In general, the mineral material from the Chagan section is not ideal for luminescence dating. This is probably due to a combination of a short transportation distance and a low number of depositional cycles the grains have undergone since they were eroded from bedrock.

Further studies of regional minerals-dosimeters should be undertaken in order to sort out the most effective luminescence dating techniques of glacial and associated sediments in the SE Altai. The small number of IRSL dates obtained does not allow us to fully evaluate appropriateness of this technique for absolute age estimation of glacial sediments in the Chagan section.

Radiocarbon dates of carbonate concretions from the bottom and the middle part of the glacial complex in the Chagan section generally correlate to each other: $22946 \pm 482$ cal. BP (SOAN 3115), $22264 \pm 657$ cal. BP (SOAN 3116), $24857 \pm 470$ cal. BP (SOAN 3117) (Rusanov and Orlova, 2013), and $30189 \pm 548$ cal. BP (SOAN 8548) (this study). It should be mentioned that this type of material is not easy and comfortable for absolute dating. Some difficulties of applying radiocarbon method for carbonate concretions dating have been previously discussed (Aitken, 1990 and Bowman, 1995). Problems of radiocarbon age measurements for lacustrine carbonate samples from the Pleistocene Lake Lahontan, Nevada, USA are presented by Lin and coauthors (Lin et al., 1996). They reported systematically younger ages and suggest it arises as result of problems of contamination with secondary calcite and the local reservoir age correction.

Radiocarbon dates of carbonate concretions argue for the relatively young age of their formation. An inverse stratigraphic sample position in the section (the older samples are located above the younger ones) could be explained by intensive Chagan river incision into the previously accumulated glacial deposits at the end of the Late Pleistocene during the interglacial time (Butvilovsky, 1993).

Heavily damaged section of the upper tooth (Equus $s p$.), presumably of the late Pleistocene age, is a single palaeontological find which was done at the bottom of upper part of the section about $100 \mathrm{~m}$ below the surface (Rusanov, 2011). This fragment, especially taking into account the state of preservation, is insufficient to determine the age of inclosing sediments (Foronova I.V., IPGGP SB RAS, personal communication).

Thus, it could be stated that number of glaciations associated with the glacial sediments of the Chagan section (Borisov, 1984 and Quaternary System, 2008) is overestimated and their chronology is not currently proved. A similar conclusion was also made by Zol'nikov and Mistryukov (2008) and Rusanov (2011). Deposits, previously interpreted as Akkem moraines (the end of the Late Pleis- 
tocene) (Borisov, 1984), are actually landslide which is composed of alluvium sediments of the Bashkaus suit. Only on top it is clothed by a thin moraine cover. Generally by now the Chagan section could hardly serve as a reference section for the Altai stratigraphy. Further geochronological researches based on modern absolute dating techniques are needed to make stratigraphic breakdown and correlations.

\section{CONCLUSION}

Our detailed geomorphological investigations argue for presence at least two major Pleistocene glaciations in a region. These results support a scheme of glaciation history within the SE Altai suggested by Devyatkin (1965) and Okishev (1982). Analysis of all available numerical age estimations of glacial and associated deposits for the reference Chagan section, SE Altai, indicates that glacial environment is one of the most complex for absolute dating.

The presented luminescence ages, obtained with both naturally and artificially saturating TL techniques showed the best data correlation in the lens of glacio-lacustrine sediments at the bottom of glacial part of the Chagan section and suggested its possible Middle Pleistocene age. The age of basal moraine as well as the time of glacial sedimentation above the lens is not reliably established. Numerous TL dates revealed a large spread in the obtained ages measured in different laboratories on the basis of various techniques. The dates sometimes poorly agree with the stratigraphic position of the sample in the section. The obtained results demonstrate that TL method is not suitable for dating glacial sediments and available TL ages cannot be treated as geochronological markers. It should only cautiously be used for making any reconstructions and correlations.

Three IRSL dates indicate Middle Pleistocene age in the upper part of the section. The small number of obtained IRSL dates cannot form the basis for geochronological reconstructions of the Pleistocene glaciations in the SE Altai, but gives the possibility for further experiments with different variation of OSL (IRSL) techniques.

The available radiocarbon dates of carbonate concretions from this section are significantly younger and indicate the age inversion of their formation. Generally, they fall into interglacial period before Sartan glaciation and indicate the probable Chagan river incision into the ancient glacial deposits which were accumulated long before.

Analysis of the physical properties of mineralsdosimeters reveals specific regional quartz features such as strong low temperature peak in TL signal which often makes it impossible to measure luminescence at chronometrical peak near $300^{\circ} \mathrm{C}$. Strong response to IR stimulation is provided by feldspar inclusions. Relatively low number of depositional cycles for the mineral grains in this section and a short transport distance was established.
Thus, further experiments on selecting the appropriate mineral and luminescence dating technique are still relevant.

It could be stated that by now the age of Pleistocene glacial landforms and sediments within the Russian Altai remains a mainly relative determination and such age markers as "Late" or "Middle Pleistocene" mean mainly relative terms "older" - "younger". The large spread in ages of deposits in reference sections within the Russian Altai and the weak provision of some of them with absolute dates do not allow the correlation of glaciations between different oroclimatical zones of Russian Altai, or further comparison with the other mountain systems of Central Asia and Siberia. The adopted scheme of correlation between Altai and Siberia glaciations, based on the first TL dates of the Chagan section, needs to be improved.

\section{ACKNOWLEDGMENT}

The study was supported by state assignment project (0330-2016-0015) and partly funded by RFBR foundation (grants 15-05-06028; 16-05-01035).

\section{REFERENCES}

Afanas'ev SL, 1990. Nanocyklitny metod opredelenija geologicheskogo vozrasta chetvertichnyh otlozhenij (Nanocycle technique of the geological age determination for Quaternary deposits). Novosibirsk, Nauka SO RAN Publisher: 123pp (in Russian).

Agatova AR, 2003. Oledenenija i activnaja tektonika: ih vzaimosvjaz' na territorii yugo-vostochnogo Altaja (Glaciations and active tectonic: their interconnection within the Southeastern Altai). Izvestija Russkogo Geograficheskogo Obschestva 135(5): 16-22 (in Russian).

Agatova AR, 2005a. Tectonic control of the Pleistocene glacial sedimentation in the Altai mountains (orogenic belt of South Siberia). Geophysical Research Abstracts 7, EGU2005-07922.

Agatova AR, 2005b. Geomorphologic mapping of the Chagan-Uzun river basin: a reference for reconstructing history of Pleistocene glaciations in the Southeastern Altai. Stratigraphy and Geological Correlation 13(6): 656-666.

Agatova AR, Novikov IS, Vysotsky EM and Gibsher AS, 2004. Geomorfologicheskie effekty zemletrjasenij 27 sentjabrja i 1 oktjabrja $\mathrm{v}$ Gornom Altae (Geomorphological effects from 27.09.2003 and 01.10.2003 earthquakes in Gorny Altai)). Geomorfologiya 3: 3-12 (in Russian).

Agatova AR, Nepop RK and Vysotsky EM, 2006. Seismogravitacionnye paleodislokacii v doline reki Chagan (Yugo-Vostochnyj Altai, Rossija) (Seismogravitational paleodislocations in Chagan river valley (SE Altai, Russia)). Geomorfologiya 4: 53-62 (in Russian).

Agatova AR, Nazarov AN, Nepop RK and Rodnight H, 2012. Holocene glacier fluctuations and climate changes in the southeastern part of the Russian Altai (South Siberia) based on a radiocarbon chronology. Quaternary Science Reviews 43: 74-93, DOI 10.1016/j.quascirev.2012.04.012.

Agatova AR, Nepop RK and Rodnight H, 2014. On the problems of correlating the Pleistocene glacial deposits in Russian Altai with Siberian stratigraphic scales. In: Rocha R, Pais J, Kullberg JC and Finney S, eds., STRATI 2013 First International Congress on Stratigraphy At the Cutting Edge of Stratigraphy. Springer. 903-907. ISBN: 978-3-319-04363-0.

Agatova AR, Nepop RK, Bronnikova MA, Slyusarenko IYu and Orlova LA, 2016. Human occupation of South Eastern Altai highlands 
(Russia) in the context of environmental changes. Archaeological and Anthropological Sciences 8: 419-440, DOI 10.1007/s12520014-0202-7.

Aitken MJ, 1985. Thermoluminescence Dating. London, Academic Press: 359pp.

Aitken MJ, 1990. Science-Based Dating in Archaeology. London, Longman: $359 \mathrm{pp}$.

Aitken MJ, 1998. An Introduction to Optical Dating. Oxford, Oxford University Press: $267 \mathrm{pp}$.

Arhipov SA, Devyatkin EV and Shelkoplyas VN, 1982. Correljacija chetvertichnyh otlozhenij Yuzhnoj Sibiri, Gornogo i Mongol'skogo Altaja, Vostochnoj i Zapadnoj Mongolii. Problemy stratigrafii i paleogeografii pleistocena Sibiri (Correlation of Quaternary deposits of Southern Siberia, Gorny and Mongolian Altai, Eastern and Western Mongolia. Problems of the Pleistocene stratigraphy and paleogeography of Siberia). Proceedings of the IGG SO AN SSSR, Novosibirsk: 149-161 (in Russian).

Baryshnikov G, 1992. Razvitie reljefa perehodnyh zon gornyh stran $v$ kajnozoe (na primere Gornogo Altaja) (Cenozoic landscape development in transitional zones of orogens (by the example of Gorny Altai). Tomsk, Tomsk University Press: 182pp (in Russian).

Baryshnikov G, Panin A and Adamiec G, 2015. Geochronology of the late Pleistocene catastrophic Biya debris flow and the Lake Teletskoye formation, Altai Region, Southern Siberia. International Geology Review DOI: 10.1080/00206814.2015.1062733.

Benn DI and Owen LA, 2002. Himalayan glacial sedimentary environments: A framework for reconstructing and dating the former extent of glaciers in high mountains. Quaternary International 9798: 3-25, DOI 10.1016/S1040-6182(02)00048-4.

Bogachkin BM, 1981. Istoriya tektonicheskogo razvitiya Gornogo Altaya v kajnozoe (The history of the Cenozoic tectonic development of Gorny Altai). Moscow, Nauka: 132pp (in Russian).

Borisov BA, 1984. Altae-Sajanskaja gornaja oblast' (Altai-Sayan Mountain province). Stratigraphy of the USSR. Quaternary system. Moscow, Nedra: 331-351pp (in Russian).

Bowman S, 1995. Radiocarbon Dating. London, British Museum Press: $64 \mathrm{pp}$.

Butvilovsky VV, 1993. Paleogeografiya poslednego oledenenija $i$ golocena Altaja: Sobytijno-Katastroficheskaja model' (Paleogeography of the Last Glaciation and the Holocene of Altai: a Catastrophic Events Model). Tomsk, Tomsk University Press: 253pp (in Russian).

Butvilovsky VV, Panychev VA and Lammert AK, 1991. O vozraste, morfologii i istorii razvitija poslednego oledenenija Vostochnogo Altaja (Age, morphology and history of development of the last glaciation of Eastern Altai). Materialy Glaciologicheskih Issledovanij 73: 36-43 (in Russian).

Butvilovsky VV, Butvilovskaya TV and Avvakumov AE, 1996. Sostavlenie geomorfologicheskoj karty Gornogo Altaja masshtaba(1:500000). Otchet regional'noj partii o rezul'tatah NIR, provedennyh v 1989-1996 godah (Geomorphological mapping of Gorny Altai. Report of the regional geological group on the scientific researches carried out in 1989-1996). Novokuznetck, State registration number 13-89-106/1 (in Russian).

Buylaert JP, Murray AS, Thomsen KJ and Jain M, 2009. Testing the potential of an elevated temperature IRSL signal from K-feldspar. Radiation Measurements 44: 560-565, DOI 10.1016/j.radmeas.2009.02.007

Carling PA, Kirkbride AD, Parnachev S, Borodavko PS and Berger GW, 2002. Late Quaternary catastrophic flooding in the Altai Mountains of south-central Siberia: A synoptic overview and introduction to flood deposit sedimentology. In: Martini IP, Baker VR and Garzón G, eds., Flood and Megaflood Processes and Deposits: Recent and Ancient Examples. International Association of Sedimentologists, Special Publication 32: 17-35.

Cunningham WD, Windley BF, Dorjnamjaa D, Badamgarov $\mathrm{J}$ and Saandar M, 1996. Late Cenozoic transpression in southwestern Mongolia and the Gobi Altai-Tien Shan connection. Earth and Planetary Science Letters 140: 67-81, DOI 10.1016/0012821X(96)00048-9.
Derevyanko AP and Molodin VI, 2000. Fenomen Altajskih mumij (Phenomenon of Altai Mummies). Novosibirsk, Publishing House of the Institute of Archaeology and Ethnography, SB RAS: 320pp (in Russian).

Devyatkin EV, 1965. Kajnozojskie otlozhenija I neotektonika Yugovostochnogo Altaja (Cenozoic deposits and neotectonics of Southeastern Altai). Moscow, USSR Academy of Science: 244pp (In Russian).

Efimtcev NA, 1961. Chetvertichoe oledenenie zapadnoj Tuvy $i$ vostochnoj chasti Gornogo Altaja (Quaternary glaciation of western Tyva and eastern part of Gorny Altai). Moscow, USSR Academy of Science Publisher: 163pp (in Russian).

Fuchs $\mathrm{M}$ and Owen LA, 2008. Luminescence dating of glacial and associated sediments: review, recommendation and future directions. Boreas 37: 636-659, DOI $10.1111 / \mathrm{j} .1502-$ 3885.2008.00052.x.

Faustov SS, Kulikov OA and Svitoch AA, 1971. Paleomagnitnye issledovanija novejshih otlozhenij $v$ doline reki Chagan (Paleomagnetic studies of new deposits in the Chagan river valley). In: Zubakov VA and Suzdalskiy OV eds., Problems of correlating new deposits of the northern Eurasia, Leningrad, Russian Geographical Society Publisher: 74-77 (in Russian).

Galakhov VP and Samoylova SYu, 2007. Oledenenie hrebta Sajljugem (YuV Altai) vo vremja maksimuma poslednego oledenenija (Glaciations of the Sailjugem range (SE Altai) during the maximum of the Last Glacial). Prirodnye resursy Gornogo Altaja 2: 36-38 (In Russian).

Gemmell AMD, 1997. Fluctuations in the thermoluminescence signal of suspended sediment in an alpine glacial meltwater stream. Quaternary Science Reviews 16: 281-290, DOI 10.1016/S02773791(96)00087-X.

Gemmell AMD, 1999. IRSL from fine-grained glaciofluvial sediment. Quaternary Science Reviews 18: 207-215, DOI 10.1016/S02773791(98)00053-5.

Glushankova NI and Voskresenskaja TN, 2008. Rekonstrukcija paleoobstanovok pleistocenovogo sedimentogeneza $\mathrm{v}$ prilednikovyh vodoemah Gornogo Altaja (Paleoenvironmental reconstructions of the Pleistocene sedimentation in the periglacial lakes of Gorny Altai). Izvestija Russkogo Geograficheskogo Obschestva 140(2): 49-57 (in Russian).

Godfrey-Smith DI, Huntley DJ and Chen WH, 1988. Optical dating studies of quartz and feldspar sediment extracts. Quaternary Science Reviews 7: 373-380, DOI 10.1016/0277-3791(88)90032-7.

Gribenski N, Blomdin RL, Caffee MW, Gaar D, Harbor JM, Hättestrand C, Heyman J, Ivanov MN, Jansson K, Lifton NA, Lowick S, Orkhonselenge A, Petrakov D, Preusser F, Rogozhina I, Rudoy A, Stroeven AP, Trauerstein M, Zhang W and Zhao JD, 2014. Comparison of different methods for dating glacial features in Central Asia. Geophysical Research Abstracts. Vol. 16, EGU20148023

Gribenski N, Jansson KN, Lukas S, Stroeven AP, Harbor JM, Blomdin R, Ivanov MN, Heyman J, Petrakov DA, Rudoy A, Clifton T, Lifton NA and Caffee MW, 2016. Complex patterns of glacier advances during the late glacial in the Chagan Uzun Valley, Russian Altai. Quaternary Science Reviews 149: 288-305, DOI 10.1016/j.quascirev.2016.07.032.

Herget J, 2005. Reconstruction of Pleistocene Ice-dammed Lake Outburst Floods in Altai-mountains, Siberia. Geological Society of America, Special Publication 386: 118pp.

Il'ichev VA, Kulikov OA and Faustov SS, 1973. Novye dannye paleomagnitnyh i termoljuminescentnyh issledovanij otlozhenij razreza Chagan (Gornyj Altai) (New data of paleomagnetic and thermoluminescent researches of deposits in the Chagan section (Gorny Altai)). In: Zubakov VA, ed., The Pleistocene chronology and climatic stratigraphy. Leningrad, Geographical Society of USSR: 252-257 (in Russian).

Ivanovsky LN, 1956. Ob osobennostjah drevnego oledenenija YugoVostochnogo Altaja (About the features of ancient glaciation of the Southeastern Altai). Proceedings of Tomsk State University 133: 149-155 (in Russian). 
Ivanovsky LN, 1967. Formy lednikovogo reljefa i ih paleogeograficheskoe znachenie na Altae (Glacial landforms and their paleogeographical significance in the Altai). Leningrad, Nauka: 263pp (in Russian).

Lehmkuhl F, Zander A and Frechen M, 2007. Luminescence chronology of fluvial and aeolian deposits in the Russian Altai (Southern Siberia). Quaternary Geochronology 2: 195-201, DOI 10.1016/j.quageo.2006.04.005.

Lehmkuhl F, Klinge M and Stauch G, 2011. The Extent and Timing of Late Pleistocene Glaciations in the Altai and Neighboring Mountain Systems. In: Ehlers J, Gibbard PL and Hughes PD, eds., Quaternary Glaciations - Extent and Chronology. A Closer Look. Amsterdam, Elsevier: 967-979.

Lin JC, Broecker WS, Anderson RF, Hemming S, Rubenstone JN and Bonani G, 1996. New ${ }^{230} \mathrm{Th} / \mathrm{U}$ and ${ }^{14} \mathrm{C}$ ages from Lake Lahontan carbonates, Nevada, USA, and a discussion of the origin of initial thorium. Geochimica et Cosmochimica Acta 60(15): 2817-2832, DOI 10.1016/0016-7037(96)00136-6.

Mikhailova IV, Khazin LB and Agatova AR, 2004. Issledovanie vozmozhnostej palinologicheskogo i mikrofaunisticheskogo metodov v raschlenenii lednikovyh i vodno-lednikovyh otlozhenij gornyh stran (na primere Altaja) (Studying the opportunities of palinological and microfauna methods of separating glacial and glacial-fluvial deposits within mountain provinces (by the example of Altai)). Proceedings of the XXVIII Plenum of Geomorphological Commission, Russian Academy of Science, Novosibirsk, IG SB RAS: 188-190 (in Russian).

Molnar P and Tapponnie P, 1975. Cenozoic tectonics of Asia: Effects of a continental collision. Science 189: 419-426, DOI 10.1126/science.189.4201.419.

Narama C, Kondo R, Tsukamoto S, Kajiura T, Ormukov C and Abdrakhmatov K, 2007. OSL dating of glacial deposits during the Last Glacial in the Terskey-Alatoo Range, Kyrgyz Republic. Quaternary Geochronology 2: 249-254, DOI 10.1016/j.quageo.2006.06.007.

Novikov IS, 2004. Morfotektonika Altaja (Morphotectonics of the Altai Mountains). Novosibirsk, SO RAN Publisher, "Geo" Brunch: $313 p p$ (in Russian).

Novikov IS, Vysotsky EM and Agatova AR, 2004. Neotectonic Type Structure of Contraction, Shear, and Extension of the Northern Part of Great Altai. Russian Geology and Geophysics 45(11): $1248-1258$.

Okishev PA, 1982. Dinamika oledenenija Altaja v pozdnem Pleistocene $i$ golocene (The Dynamics of Glaciation in Altai during the Late Pleistocene and Holocene). Tomsk, Tomsk University Press: 210pp (in Russian).

Okishev PA, 1987. K voprosu o razmerah srednepleistocenovogo oledenenija Altaja (To the question of the size of the Middle Pleistocene glaciation in Altai). Voprosy geografii Sibiri 17: 3-12 (in Russian).

Okishev PA, 2011. Reljef i oledenenie Russkogo Altaja (Relief and glaciation of Russian Altai). Tomsk, Tomsk University Press: 382pp (in Russian).

Perevalov AV and Rezanov IN, 1997. Pervyj opyt radiotermoljuminescentnogo datirovanija antropogenovyh otlojenij zapadnogo $\mathrm{Za}-$ baikalia (First attempt of radiothermoluminescence dating of anthropogenic deposits from western Transbaikalia). Russian Geology and Geophysics 38(7): 1245-1251 (in Russian).

Popov VE, 1972. O vozmozhnosti primenenija geomorfologicheskogo kriterija k opredeleniju vozrasta chetvertichnyh otlozhenij v Chaganskom opornom obnazhenii na Altaje (About the possibility of using geomorphological criteria to determine the age of the Quaternary deposits in the Chagan-Uzun reference section in the Altai). Gljaciologija Altaja 7: 104-114 (in Russian).

Quaternary System, 2008. Postanovlenija Mezhvedomstvennogo stratigraficheskogo komiteta i ego postojannyh komissij (Resolution of Russian Interdepartmental Stratigraphic Committee and its permanent commissions). St. Petersburg, VSEGEI Publisher, 38: 115-127 (in Russian).
Raukas A and Stankowski W, 2005. Influence of sedimentological composition on OSL dating of glaciofluvial deposits: eexamples from Estonia. Geological Quarterly 49(4): 463-470.

Reimer P, Baillie M, Bard E, Bayliss A, Beck J, Blackwell P, Bronk Ramsey C, Buck C, Burr G, Edwards R, Friedrich M, Grootes P, Guilderson T, Hajdas I, Heaton T, Hogg A, Hughen K, Kaiser K, Kromer B, McCormac F, Manning S, Reimer R, Richards D, Southon J, Talamo S, Turney C, Plicht J and Weyhenmeyer C, 2009. IntCal09 and Marine 09 radiocarbon age calibration curves, 0-50,000 years cal BP. Radiocarbon 51(4): 1111-1150.

Reuther A, Herget J, Ivy-Ochs S, Borodavko P, Kubik PW and Heine $\mathrm{K}, 2006$. Constraining the timing of the most recent cataclysmic flood event from ice-dammed lakes in the Russian AltaiMountains, Siberia, using cosmogenic in situ 10Be. Geology 34: 913-916, DOI 10.1130/G22755A.1.

Richards BWM, 2000. Luminescence dating of quaternary sediments in the Himalaya and High Asia: a practical guide to its use and limitations for constraining the timing of glaciation. Quaternary International 65-66: 49-61, DOI 10.1016/S1040-6182(99)00036-1.

Rudoy AN, 1995. Geomorfologicheskij effect i gidravlika pozdnepleistocenovyh jökulhlaupov lednikovo-podprudnyh ozer Altja (Geomorphological effect and hydraulics of the Late Pleistocene jökulhlaups of the ice-dammed lakes in Altai). Geomorfologija 4: 61-76 (in Russian)

Rudoy AN, Lysenkova ZV, Rudsky VV and Shishin MY, 2000. Ukok (Proshloe, Nastoyaschee i Budusheee) (Ukok (Past, Present and Future)). Barnaul, Altai State University: 176pp (in Russian).

Rudoy AN, 2005. Gigantskaja rjab' techenija (Giant Current Ripples). Tomsk, Tomsk State University: 224pp (in Russian).

Rudoy AN, 2013. Novye dannye o vozraste lednikovyh i ozernyh otlozhenij v bassejne Teleckogo ozera (New data about the age of the glacial and lacustrine sediments in the Lake Teletskoye basin). Izvestija Russkogo Geograficheskogo Obschestva 1: 36-41 (in Russian).

Rudoy AN and Kirjanova MR, 1996. Erozionnye terrasy i ekzogennaja geomorfologija Severo-Vostochnogo Sajljugema, bassejn Chujskoj kotloviny, Gorny Altaj (Erosion terraces and exogenous geomorphology of northeastern Sajlyugem, Chuya basin, Gorny Altai). Geomorfologija 1: 87-96 (in Russian).

Rusanov GG, 2008. Maksimaljnyj uroven' Chujskogo lednokovopodprudnogo ozera $\mathrm{v}$ Gornom Altae (The maximum level of the Chuya glacier-dammed lake in Gorny Altai). Geomorfologija 1: 65-71 (in Russian).

Rusanov GG, 2009. Osobennosti pozdnevjurmskogo oledenenij bassejna reki Eskongo v Gornom Altae (Peculiarities of Late Wurm glaciation of the Eskongo River basin, Gorny Altai). Izvestija Russkogo Geograficheskogo Obschestva 141(5): 59-64 (in Russian).

Rusanov GG, 2011. Razrez Chagan (Yugovostochyj Altaj): stroenie i rekonstrukcija uslovij osadkonakoplenija (The Chagan section (Southeastern Altai): structure and reconstruction of the depositional conditions). Izvestija Russkogo Geograficheskogo Obschestva 143(1): 67-72 (in Russian).

Rusanov GG and Vazhov SV, 2014. Opornye chetvertichnye razrezy Gornogo Altaja (Bele, Kubadru, Chagan) (Reference Quaternary sections of Gorny Altai (Bele, Kubadru, Chagan)). Bijsk, FGBOU VPO "AGAO": 163pp (in Russian).

Rusanov GG and Orlova LA, 2013. Radiouglerodnye datirovki (SOAN) Gornogo Altaja $i$ Predaltaiskoj ravniny (Radiocarbon Dates (SOAN) of Gorny Altai and Altai Foreplain). Bijsk, "Biya" Publisher: 163pp (in Russian).

Rusanov VI, 1961. Raspredelenie srednegodovogo kolichestva osadkov $\mathrm{v}$ Central'nom Altae (Distribution of annual precipitation in Central Altai). (Izvestiya Vserossijskogo geologicheskogo obshchestva 93(6): 272-283 (in Russian).

Selegey VV and Selegey T., 1978. Teleckoe ozero (Lake Teletskoe). Leningrad, Gidrometeoizdat: 143pp (In Russian).

Sheinkman VS, 1990. Pleistocenovoe oledenenie gor Sibiri: analiz i novye dannye (Pleistocene glaciations of mountains of Siberia: analysis and new data). Materialy of Glaciologicheskih Issledovanij 69: 78-85 (in Russian). 
Sheinkman VS, 2002. Testirovanie SS tehnologii termoluminescentnogo datirovanija na razrezah mertvogo morja, ee ispol'zovanie $\mathrm{v}$ Gornom Altae i paleogeograficheskaja interpretacija rezul'tatov (Testing the S-S technique of TL dating on the Dead Sea sections, its use in the Altai Mountains and palaeogeographic interpretation of results). Arheologija, Etnografija i Antropologija Evrasii 2(10): 22-37 (in Russian).

Shlukov AI, Usova MG, Shakhovets SA and Voskovskaya LT, 1997. New techniques of absolute dating of Quaternary sediments. World wide web http://www.aha.ru/ shlukov/method.htm

Stroeven AP and the Central Asia Paleoglaciology Project (CAPP) Team, 2015. Spatial and temporal patterns of paleoglaciation across eastern Tibet and Central Asia. Geophysical Research Abstracts 17: EGU2015-14538.

Stuiver M and Reimer PJ, 1993. Extended C-14 data-base and revised calib 3.0 C-14 age calibration program.

Svitoch AA, Boyarskaya TD, Voskresenskaya TN, Glushakova II, Evseev AV, Kursalova VI, Parmonova NN, Faustov SS and Khorev VS, 1978. Razrez novejshih otlozhenij Altaja (The sections of the latest deposits of Altai). Moscow, MSU Publisher: 208pp (in Russian).

Thomsen KJ, Murray AS, Jain M and Bøtter-Jensen, 2008. Laboratory fading rates of various luminescence signals from feldspar-rich sediment extracts. Radiation Measurements 43: 1474-1486, DOI 10.1016/j.radmeas.2008.06.002.

Tsukamoto S, Asahi K, Watanabe T and Rink WJ, 2002. Timing of past glaciations in Kanchenjunga Himal, Nepal by optically stimulated luminescence dating of tills. Quaternary International 97-98: 5767, DOI 10.1016/S1040-6182(02)00051-4.

Vlasov VK and Kulikov OA, 1989. Radiothermoluminescence Dating and Applications to Pleistocene Sediments. Physics and Chemistry of Minerals, 16: 551-558, DOI 10.1007/BF00202210.

Volkova VS and Babushkin AE, 2000. Unificirovannaja regional'naja ctratigraficheskaja shema chetvertichnyh otlozhenij ZapadnoSibirskoj Platformy (Unified regional stratigraphic scheme of Quaternary deposits of the West Siberian Plain). Novosibirsk, SNIIGGiMS: 64pp (in Russian).

Volkova VS, Borisov BA and Kamaletdinov VA, 2010. Unificirovannaja regional'naja ctratigraficheskaja shema chetvertichnyh ot lozhenij Srednej Sibiri (Taymyr, Sibirskaja Platforma) (Unified regional stratigraphic scheme of Quaternary deposits of the middle Siberia (Taymyr, Siberian platform)). Novosibirsk, SNIIGGiMS: 90pp (in Russian).

Vysotsky EM, 2003. Gljacial'naja geomorfologija obramlenija Teleckogo ozera (Glacial geomorphology of framing area of the Teletskoye Lake). Geomorfologija 3: 44-54 (in Russian).

Ufimtsev GF, 2002. Morfotectonica Eurasii (Morphotectonic of Eurasia). Irkutsk, Irkutsk State University: 494pp (in Russian).

Wagner GA, 1998. Age Determination of Young Rocks and Artifacts. Berlin Heidelberg, Springer: 466pp.

Yarmolyuk VV and Kuzmin MI, 2006. Correlation of the Late Cenozoic endogenic events and climatic variation in Central Asia. Stratigraphy and Geological Correlation 14(2): 105-125, DOI 10.1134/S0869593806020018.

Zhamoida AI, 2006. Stratigraficheskij kodeks Rossii (Stratigraphic Code of Russia). SPb.: VSEGEI Press: 96pp (in Russian).

Zhao J, Yin X, Harbor JM, Lai Z, Liu S and Li Z, 2013. Quaternary glacial chronology of the Kanas river valley, Altai mountains, China. Quaternary International 311: 44-53, DOI 10.1016/j.quaint.2013.07.047.

Zol'nikov ID and Mistrukov AA, 2008. Chetvertichnye otlozhenija i rel'ef dolin Chui i Katuni (Quaternary deposits and relief of the Chuya and Katun valleys). Novosibirsk, Parallel: 182pp (in Russian).

Zol'nikov ID, Deev EV and Lyamina VA, 2010. New data on Quaternary morpholithogenesis in the Chuya basin (Gorny Altai). Russian Geology and Geophysics 51: 339-348, DOI 10.1016/j.rgg.2010.03.002.

Zol'nikov ID, Deev EV, Kotler SA, Rusanov GG and Nazarov DV, 2016. New results of OSL dating of Quaternary sediments in the Upper Katun valley (Gorny Altai) and adjacent area. Russian Geology and Geophysics 57(6): 933-943, DOI 10.1016/j.rgg.2015.09.022

Zykin VS, Zykina VS and Smolyaninova LG, 2016. New data on the most ancient early Quaternary glaciation in Gorny Altai. Doklady Earth Sciences 466(1): 20-23, DOI 10.1134/S1028334X16010244. 